\title{
Gallrásarsteinar eftir gallblöðrutöku á Landspítala 2008-2011
}

\author{
Pórey Steinarsdóttir ${ }^{1}$ æknir, Elsa Björk Valsdóttir ${ }^{1,2}$ læknir, Páll Helgi Möller ${ }^{1,2}$ læknir
}

\section{ÁGRIP}

Inngangur: Einkenni gallsteina í gallrás geta komið fram eftir gallblöðrutöku. Ef pau koma fram innan tveggja ára er talið að steinn hafi verið til staðar við aðgerðina. Tilgangur rannsóknarinnar var að kanna pá sjúklinga sem greindust með gallrásarstein eftir að hafa farið i gallblöðrutöku á Landspítala á árunum 2008-2011.

Efniviður og aðferðir: Afturskyggn rannsókn par sem upplýsingum um sjúklinga var safnað úr sjúkraskrárkerfi Landspítala. Meðal pess sem var skráð voru lifrarpróf, niðurstöður myndgreininga, tími frá aðgerð, meðferð og fylgikvillar.

Niðurstöður: Á rannsóknartímabilinu greindust 40 sjúklingar með gallrásarstein eftir gallblöðrutöku. Meðalaldur var 50 ár (20-89) og konur voru 24 (60\%). Meðaltími frá aðgerð að greiningu gallrásarsteins voru 382 dagar. Greining var staðfest i 87,5\% tilfella. Hjá 36 sjúklingum (90\%) var brugðist við með röntgenrannsókn á gallvegum og brisgangi með holsjá. Gallrásarmyndataka með ástungu gegnum kviðvegg og lifur var gerð hjá einum sjúklingi, einn fór í opna aðgerð en premur sjúklingum batnaði án meðferðar. Prír sjúklingar fengu fylgikvilla í kjölfar meðferðar. Gallrásarsteinn greindist innan við tveimur árum frá aðgerð hjá 31 sjúklingi $(77,5 \%)$. Tídni fyrri gallrásarsteina, gildi bílirúbíns og víkkun á gallgöngum án sjáanlegs steins var svipuð, hvort sem steinar greindust snemma eða seint. Ályktun: Nær alla er hægt að meðhöndla án skurðaðgerðar. Pó meirihluti steina greinist innan tveggja ára verður ekki séð að grunur um gallrásarstein hafi átt að vakna við sjálfa gallblöðrutökuna hjá meirihluta sjúklinga.
${ }^{1}$ Skurðæækningadeild Landspítala, ${ }^{2}$ læknadeild Háskóla lslands.

Rannsókn unnin við skurðdeild Landspítala

Fyrirspurnir: Elsa Björk Valsdóttir elsava@landspitali.is

Greinin bars 14. janúar 2014 sampykkt til birtingar

7. maí 2015.

Höfundar hafa útfyllt eyðublað um hagsmunatengsl.

\section{Inngangur}

Gallsteinar og sjúkdómar tengdir peim eru algeng vandamál pó margir sem hafa gallsteina séu einkennalausir. Algengi gallsteina er 10-20\% í Evrópu og Norður-Ameríku og talið er að allt að $8 \%$ hvítra kvenna í Norður-Ameríku fari í gallblöðrutöku á lífsleiðinni. ${ }^{1-3}$ Gallblöðrutaka er ein algengasta aðgerð sem framkvæmd er á Landspítala og hafa verið gerðar á bilinu 400 til 550 gallblöðrutökur árlega á Landspítala undanfarin ár. ${ }^{4,5}$

Einkenni, sambærileg peim sem áður voru talin stafa frá steinum í gallblöðru, geta komið fram eftir að gallblaðra hefur verið fjarlægð. ${ }^{5-9}$ Pessi einkenni geta komið fram dögum, vikum eða árum síðar og geta einkennin annaðhvort verið vegna vandamála í gallrás (ductus choledocus), pá einna helst steina, eða vegna vandamála utan gallvegakerfisins. $., 6,9$

Talið er að flestir gallrásarsteinar myndist í gallblöðru og ferðist eftir gallblöðrugangi (ductus cysticus) niður í gallrás. ${ }^{5}$ Flestar rannsóknir benda til pess að steinar í gallrás sem greinast á fyrstu tveimur árum eftir gallblöðrutöku hafi verið til staðar við aðgerðina sjálfa en að peir sem greinast síðar hafi myndast í gallrás eftir aðgerð. ${ }^{5,10}$ Aðrar rannsóknir benda til pess að petta tímabil sé styttra, eða um 6 mánuðir. ${ }^{4}$ Peir steinar sem myndast í gallrás eru oftast tengdir rennslishindrun og/eða sýkingu í gallrás (cholangitis) og eru 4-10\% af öllum steinum í gallrás. ${ }^{11}$ Mikilvægt er að meðhöndla pessa undirliggjandi pætti til að koma í veg fyrir endurkomu steina síðar meir. ${ }^{5}$
Algengi steina í gallrás á fyrstu tveimur árum eftir gallblöðrutöku með kviðsjá er 1-2\% erlendis. ${ }^{5}$ Á Íslandi hefur tíðni gallrásarsteina eftir gallblöðrutöku á Fjórðungssjúkrahúsinu á Akureyri og Landspítala verið 1,5\% ${ }^{12,13}$ Lifrarprófin ALAT (Alanin transaminase), bílirúbín og alkalískur fosfatasi (Alkaline phosphatase, ALP) geta verið hjálpleg við greiningu gallrásarsteina. ${ }^{5,14}$ Ómskoðun getur sýnt fram á steina eða víkkun á gallrás en segulómun af gallrás og brisrás (Magnetice Resonance Cholangiopancreatography, MRCP) er nákvæmari til slíkrar greiningar. ${ }^{5}$

Aðalmeðferð gallrásarsteina er röntgenrannsókn á gallvegum og brisgangi með holsjá (Endoscopic Retrograde Cholangiopanreatography, ERCP) með totuskurði (sphincterotomy), annaðhvort fyrir (ef steinn er pekktur) eða eftir aðgerð. Einnig er hægt að fjarlægja gallrásarsteina í sömu aðgerð og gallblaðra er tekin í kjölfar greiningar með myndrannsókn af gallrás í aðgerð (intraoperative cholangiogram). ${ }^{15}$

Endurinnlagnir og inngrip vegna gallrásarsteina sem greinast ekki við fyrstu innlögn eru kostnaðarsamar fyrir bæði samfélagið og sjúklinginn. Tilgangur rannsóknarinnar var að kanna pá sjúklinga sem greindust með gallrásarstein á Landspítala á árunum 20082011 eftir gallblöðrutöku, bera niðurstöður saman við niðurstöður erlendra rannsókna, meta hvort gallrásarsteinar við gallblöðrutökur séu vangreindir og hvert sé hlutfall steina sem telja megi víst að hafi verið til staðar við aðgerð miðað við steina sem hafi myndast síðar. 


\section{Efniviður og aðferðir}

Rannsóknin var afturskyggn og náði til sjúklinga sem greindust með gallrásarstein með eða án sýkingar í gallrás (ICD-10 K80.3 og K80.5) á árunum 2008-2011 og höfðu áður farið í gallblöðrutöku á Landspítala. Í upphaflega rannsóknarhópnum var 51 sjúklingur en 11 voru útilokaðir frá rannsókninni af eftirfarandi ástæðum: alvarlegur gallrásarskaði $(n=1)$, röng skráning $(n=7)$ og röng greining $(\mathrm{n}=3)$. Heildarfjöldi sjúklinga í rannsókninni var pví 40. Skráð voru töluleg gildi og upplýsingar fyrsta gallrásarsteinakasts eftir gallblöðrutöku.

Upplýsingum um sjúklinga var safnað úr sjúkraskrárkerfi Landspítala. Skráð voru lifrar- og brispróf (ALAT, ALP, bílirúbín, lípasi) fyrir gallblöðrutöku og við greiningu gallrásarsteins, niðurstöður myndgreininga og speglana, ábending aðgerðar, fyrri saga um gallblöðru- eða gallrásarsýkingu og fylgikvillar gallblöðrutöku. Skráður var tími frá aðgerð að greiningu gallrásarsteins, einkenni sjúklings, hvernig gallrásarsteinn var greindur og meðferð við honum.

Tölfræði var lýsandi. Við tölfræðilega úrvinnslu gagna voru notuð tölvuforritið Excel og vefsíðan quantitativeskills.com/sisa/. Tölvuforritið R var notað til að teikna upp öfugt Kaplan-Maier graf sem sýnir tíma frá gallblöðrutöku að greiningu gallrásarsteins. Fengin voru leyfi frá Persónuvernd og siðanefnd Landspítala (Tilvísun 201001009AT, erindi 70/2009).

\section{Niðurstöður}

Heildarfjöldi sjúklinga í rannsókninni var 40. Meðalaldur sjúk-

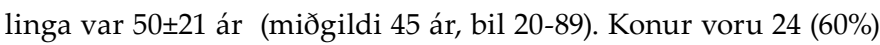
og karlmenn 16 (40\%).

\section{Gallblöðrutaka}

Ábendingar fyrir gallblöðrutöku voru gallsteinar með eða án bólgu ( $\mathrm{n}=34,85 \%)$, steinn í gallrás $(\mathrm{n}=3,7,5 \%)$ og aðrar greiningar $(\mathrm{n}=2,5 \%)$ en í einu tilfelli (2,5\%) var ábending ekki skráo.

Hjá 7 sjúklingum komu upp erfiðleikar við gallblöðrutökuna eða fylgikvillar í kjölfar hennar (17,5\%). Fjórir (10\%) fengu gallleka eftir aðgerð, hjá einum var framkvæmt hlutabrottnám á gallblöðru og hjá tveimur til viðbótar var skráð að um erfiða aðgerð hefði verið að ræða.

\section{Greining gallrásarsteins}

Allir sem greindust með gallrásarstein eftir gallblöðrutöku leituðu til læknis vegna verkja í kvið og 6 af peim höfðu einnig gulu. Greining gallrásarsteins var staðfest með myndgreiningu hjá 23 sjúklingum (ómun, tölvusneiðmynd eða segulómun af gallrás og brisrás (MRCP), með röntgenrannsókn á gallvegum og brisgangi með holsjá (ERCP)), hjá 11 sjúklingum að undangenginni myndrannsókn og hjá einum sjúkling með gallrásarmyndatöku með ástungu gegnum kviðvegg og lifur (Percutaneus Transhepatic Cholangiography, PTC) í kjölfar röntgenrannsóknar á gallvegum og brisgangi með holsjá (ERCP). Рað voru pví alls 35 sjúklingar $(87,5 \%)$ með staðfesta greiningu en ekki fékkst staðfesting klínískrar greiningar hjá 5 sjúklingum (12,5\%).

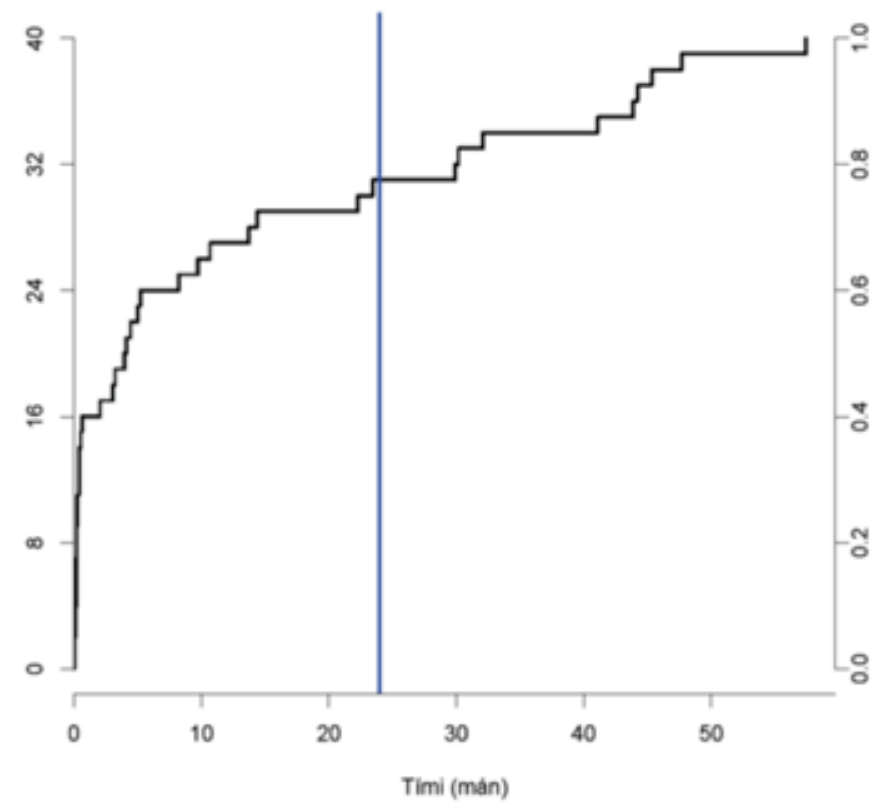

Mynd 1. Kaplan-Meier graf sem sýnir tíma frá gallblöðrutöku að greiningu gallrásarsteina. X-ás er tími og fjöldi sjúklinga er á y-ás. Bláa línan er við tvö ár. Rúmlega 3/4 hluti sjúklinga $(77,5 \%)$ greindist á fyrstu tveimur árunum eftir gallblöðrutöku.

Meðaltími frá aðgerð að greiningu gallrásarsteins var 374ะ501 dagar (miðgildi 120 dagar, bil 1-1723). Gallrásarsteinn greindist á fyrstu tveimur árum frá aðgerð hjá 31 sjúklingi (77,5\%) en hjá 9 sjúklingum (22,5\%) síðar (mynd 1). Við nánari skoðun sást að $40 \%$ (n=16) greinust strax á fyrsta mánuði eftir gallblöðrutöku og helmingur allra sem fengu gallrásarstein voru búnir að fá einkenni hans á fyrstu fjórum mánuðum eftir aðgerð. Af peim 16 sjúklingum sem greindust á fyrsta mánuði eftir aðgerð var framkvæmd gallrásarmyndataka í aðgerð hjá premur (19\%). Hjá einum vegna pekkts steins fyrir aðgerð og hjá tveimur vegna hækkunar á lifrarprófum. Hinir 13 sjúklingarnir voru ekki með óeðlileg lifrarpróf, víkkun á gallgöngum eða annað sem benti til steina í gallrás fyrir aðgerð.

Tíðni fyrri gallrásarsteina, gildi bílirúbíns og víkkun á gallgöngum án sjáanlegs steins við gallblöðrutökuna var svipað hvort sem gallrásarsteinar greindust fyrir eða seinna en tveimur árum eftir aðgerð (tafla I).

Tafla I. Samanburður sjúklingahópa sem greindust með gallrásarstein innan tveggja ára og meira en tveimur árum eftir gallblöðrutöku.

\begin{tabular}{lcc}
\hline & $\begin{array}{c}\text { Greining }<2 \text { ár } \\
(\mathrm{n}=31) \mathrm{n}(\%)\end{array}$ & $\begin{array}{c}\text { Greining } \geq 2 \text { ár } \\
(\mathrm{n}=9) \mathrm{n}(\%)\end{array}$ \\
\hline Meðalaldur (ár) & 48 & 53 \\
\hline Gallrásarsteinn fyrir aðgerð & $4(12,9)$ & $3(33,3)$ \\
\hline Bílirúbín >25 & $3(9,7)$ & $1(11,1)$ \\
\hline Víkkun gallrásar án steins & $2(6,5)$ & $2(22,2)$ \\
\hline ERCP fyrir aðgerð & $5(16,1)$ & $4(44,4)$ \\
\hline Totuskurður & $3(9,7)$ & $3(33,3)$ \\
\hline Myndrannsókn af gallrás við aðgerð & $5(16,1)$ & $4(44,4)$ \\
\hline Endurteknir gallrásarsteinar & $6(19,4)$ & $1(11,1)$ \\
\hline
\end{tabular}




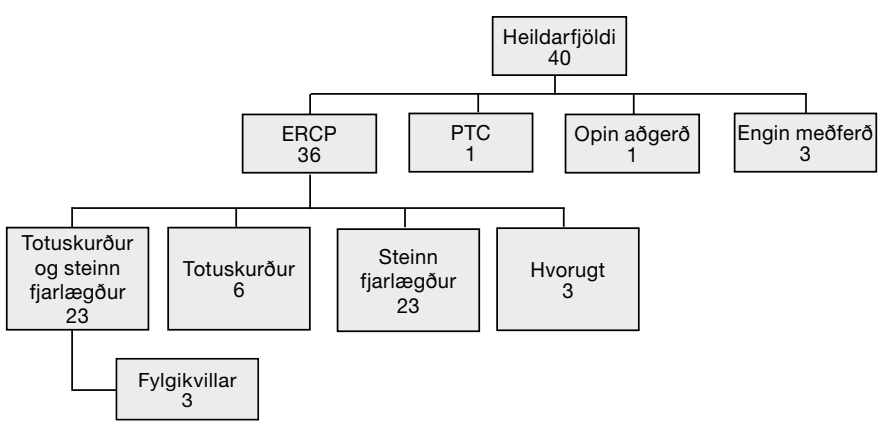

Mynd 2. Meðferð sjúklinga með gallrásarstein. Einn sjúklingur fór bæði i röntgenrannsókn á gallvegum og brisgangi með holsjá (ERCP) og gallrásarmyndatöku með með ástungu gegnum kviðvegg og lifur (PTC).

\section{Meðferð gallrásarsteina}

Algengasta meðferð við gallrásarsteini var röntgenrannsókn á gall- og brisrásarvegum með holsjá, og var hún framkvæmd hjá 36 sjúklingum (90\%) (mynd 2). Hjá einum af pessum 36 var meðferðin ófullnægjandi par sem ekki gekk að præða upp gallrás og var pví framkvæmd gallrásarmyndataka með ástungu gegnum kviðvegg og lifur í kjölfarið. Meðferð var með opinni aðgerð hjá einum sjúklingi par sem hann var með sarp (diverticulum) á skeifugörn sem gerði röntgenrannsókn á gallvegum og brisgangi með holsjá tæknilega illframkvæmanlega og vegna stærðar steins var gallrásarmyndataka með ástungu gegnum kviðvegg og lifur ekki talin ákjósanleg. Premur sjúklingum batnaði án meðferðar.

Prír sjúklingar af peim sem fóru í röntgenrannsókn á gallvegum og brisgangi með holsjá og totuskurð (8,3\%) fengu fylgikvilla í kjölfarið. Einn fékk rof á gallrás og frítt loft í kvið og var hann meðhöndlaður með föstu og sýklalyfjum. Tveir sjúklingar fengu brisbólgu og voru peir báðir meðhöndlaðir með föstu og verkjalyfjum.

\section{Endurteknir gallrásarsteinar}

Af rannsóknarhópnum voru 7 sjúklingar (17,5\%) sem fengu endurtekið gallrásarsteina eftir gallblöðrutöku. Fimm af pessum 7 (71\%) höfðu fengið fylgikvilla í kjölfar aðgerðar (n=2, 28,6\%) eða eftir meðferð fyrsta gallrásarsteins ( $n=3,42,9 \%)$. Sambærilegar tölur fylgikvilla eftir gallblöðrutöku eða meðferð fyrsta gallrásarsteins hjá peim sem fengu gallrásarstein einu sinni voru prír af $33(9 \%)$, par af tveir (6\%) í kjölfar gallblöðrutöku og einn (3\%) eftir röntgenrannsókn á gallvegum og brisgangi með holsjá.

\section{Grunur um gallrásarstein fyrir aðgerð}

Fjórtán sjúklingar höfðu pessar vísbendingar um gallrásarsteina fyrir gallblöðrutöku: hækkun á gildi bílírúbíns (n=4, 28,6\%), víkkun á gallgöngum ( $\mathrm{n}=4,28,6 \%$ ) (gallrás eða gallblöðrugangi) og steinn í gallrás á myndgreiningu $(\mathrm{n}=6,42,9 \%)$.

Af peim fjórum sem voru með hækkun á gildi bílirúbíns fóru tveir í segulómun af gallrás og brisrás (MRCP) fyrir aðgerð. Hjá öðrum greindist gallrásarsteinn sem var staðfestur með myndrannsókn af gallrás við aðgerð og var ákveðið að fjarlægja hann með röntgenrannsókn á gallvegum og brisgangi með holsjá daginn eftir aðgerð. Pá fannst enginn steinn en gerður var totuskurð- ur. Hjá hinum fannst ekki gallrásarsteinn, hvorki við segulómun af gallrás og brisrás né við röntgenrannsókn á gall- og brisrásarvegum með holsjá sem framkvæmd var í kjölfarið. Sá sjúklingur var einkennalaus í rúmlega fjögur ár eftir gallblöðrutökuna. Hinir tveir sem voru með hækkun á gildi bílirúbíns fengu enga frekari uppvinnslu. Hvorugur peirra greindist með gallrásarstein á upphaflegri myndgreiningu (ómun) en gallgangar utan lifrar voru tormetnir. Báðir pessir sjúklingar greindust með gallrásarstein innan fjögurra mánaða frá aðgerð.

Fjórir sjúklingar greindust með víkkun á gallgöngum en engan stein á upphaflegri myndgreiningu. Einn var með frábendingu fyrir segulómun af gallrás og brisrás. Pví var reynt að gera röntgenrannsókn á gallvegum og brisgangi með holsjá sem gekk ekki. Pegar hann kom til valaðgerðar var hann einkennalaus og myndrannsóknir pví ekki endurteknar. Gallrásarsteinar greindust 5 mánuðum eftir gallblöðrutökuna. Hinir prír fóru hvorki í segulómun af gallrás og brisrás né röntgenrannsókn á gallvegum og brisgangi með holsjá fyrir aðgerð. Hjá einum var gerð myndrannsókn af gallrás við aðgerð, sem var eðlileg og var hann steinalaus í rúm prjú ár. Annar fór í tölvusneiðmynd fyrir aðgerð sem sýndi víkkun á gallrás og grun um að steinn hefði gengið niður. Steinn var fjarlægður úr gallblöðrugangi við aðgerð, en ekki var gerð frekari myndrannsókn eftir aðgerð. Sjúklingur greindist með gallrásarstein fjórum árum síðar. Priðji sjúklingurinn greindist með víkkun á gallblöðrugangi á ómun fyrir aðgerð og grun um Mirizzi-heilkenni. Gallrás var eðlilega víð. Sjúklingurinn fór í segulómun af gallrás og brisrás strax eftir aðgerð og aftur viku seinna vegna kviðverkja en í bæði skiptin voru niðurstöður rannsóknar eðlilegar. Ekki tókst að sýna fram á að gallrásarsteinn ylli peim einkennum en par sem önnur skýring fannst ekki var sú klíníska greining sett.

Auk ofangreindra sjúklinga greindust 6 sjúklingar með gallrásarstein á myndgreiningu fyrir aðgerð. Enginn peirra var með hækkað gildi bílirúbíns. Peir fóru allir í röntgenrannsókn á gallvegum og brisgangi með holsjá fyrir aðgerð $(n=5)$ og/eða myndrannsókn af gallrás við aðgerð $(n=4)$.

\section{Umræða}

Almennt er talið að 1-2\% sjúklinga sem gangast undir gallblöðrutöku fái síðar gallrásarstein. ${ }^{4}$ Á Landspítala eru árlega gerðar 400550 aðgerðir par sem gallblaðra er fjarlægð og er áætlað algengi gallrásarsteina eftir gallblöðrutöku pví um 2-3\%. Gallrásarsteinn var oftast greindur á fyrstu tveimur árunum eftir gallblöðrutöku, pað er hjá premur af hverjum fjórum sjúklingum. Langflestir greinast á fyrsta mánuði eftir gallblöðrutöku og helmingur peirra sem fá gallrásarstein eftir aðgerð hafa fengið einkenni um hann á fyrstu fjórum mánuðunum eftir hana. Мiðað við algeng viðmið má álíta að peir steinar hafi verið til staðar við aðgerð og að hugsanlega hefði mátt finna pá með frekari uppvinnslu. ${ }^{5,10}$ Hjá 11 sjúklingum komu gallrásarsteinar fram eftir tvö ár og má pá ætla að peir hafi myndast síðar í gallrás og pví ómögulegt að sjá pá fyrir eða bregðast við peim pegar aðgerð var framkvæmd.

Notkun myndrannsóknar af gallrás í aðgerð er mjög mismunandi eftir löndum, spítölum og skurðlæknum. Sumstaðar er alltaf gerð myndrannsókn á gallrás, til dæmis í Svípjóð par sem haldin 
er nákvæm skráning á aðgerðum vegna gallsteina á landsvísu. ${ }^{16}$ Á Landspítala tíðkast almennt ekki að framkvæma myndrannsókn á gallrás við gallblöðruaðgerðir nema í völdum tilfellum, til dæmis pegar grunur er um gallrásarstein eða ef líffærafræðin er óljós. Rannsóknir hafa hins vegar verið misvísandi um hvort ábending sé fyrir reglubundinni myndrannsókn á gallrás við aðgerðir eða ekki. Ekki hefur verið sýnt fram á með óyggjandi hætti að skaði á gallrás sé sjaldgæfari með myndrannsókn í aðgerð en án hennar. Hins vegar finnast oftar steinar í gallrás pegar myndrannsókn er gerð og aðgerðartími lengist. Myndrannsókn fylgir hins vegar sjálfstæð hætta á fylgikvillum eins og við öll inngrip, til dæmis bandvefsmyndun og prenging í gallrás með tilheyrandi vandamálum. 15,17,18 Рað er pví ekki sjálfgefið að aukin notkun myndrannsókna í aðgerð sé sjúklingum fyrir bestu. Eitt af pví sem getur dregið úr pörfinni fyrir myndrannsókn í aðgerð er aðgengi að segulómun af gallrás og brisrás fyrir aðgerð. Á Landspítala er slíkt aðgengi fyrir sjúklinga með gallsteinavandamál til fyrirmyndar og komast peir iðulega að í pá rannsókn innan sólarhrings.

pegar greindir hafa verið steinar í gallrás eru ýmsir meðferðarmöguleikar. Ef steinninn er pekktur fyrir aðgerð eða greinist í aðgerð má reyna að skola honum niður í skeifugörn með pví að præða legg í gallblöðrugang. Annar möguleiki á meðferð í skurðaðgerð er að opna gallrásina og sækja steinninn. Petta er hægt að gera hvort sem er í opinni aðgerð eða í gegnum kviðsjá, ef hæfni skurðlæknis leyfir. Algengast er hins vegar að meðhöndla steina í gallrás með röntgenrannsókn á gallvegum og brisgangi með holsjá ${ }^{15}$, hvort sem peir greinast fyrir, í eða eftir aðgerð. Okkar niðurstöður voru í samræmi við petta par sem 36 af 40 sjúklingum fóru í röntgenrannsókn á gallvegum og brisgangi með holsjá. Pó röntgenrannsókn á gallvegum og brisgangi með holsjá sé mun minna inngrip en að opna gallrásina í aðgerð og hægt sé að fjarlægja alla steina í 95\% tilfella er pað ekki hættulaust. Pekktir fylgikvillar eru briskirtilsbólga hjá 3-10\% sjúklinga, gallrásarbólga, blæðing og rof á skeifugörn eða gallrás. ${ }^{19,20}$ Hjá okkur komu fram fylgikvillar hjá premur sjúklingum af 36 og eru pær tölur ásættanlegar miðað við pað sem lýst er annars staðar. Раð sama gildir um aðgengi að röntgenrannsókn á gallvegum og brisgangi með holsjá á Landspítala og segulómun af gallrás og brisrás. Yfirleitt komast sjúklingar í röntgenrannsókn á gallvegum og brisgangi með holsjá innan ásættanlegs tíma, pó stundum sé biðtíminn nokkrir dagar.

Vert er að skoða sérstaklega pá sjúklinga par sem grunur var um gallrásarstein fyrir aðgerð. Peir voru alls 14 og voru 12 peirra unnir upp með tilliti til gallrásarsteins. Tveir sjúklingar voru hins vegar með hækkað gildi bílirúbíns án pess að hafa fengið frekari uppvinnslu og greindust peir báðir með gallrásarstein á fyrstu 6 mánuðunum eftir gallblöðrutöku. Ekki var hægt að sjá í rannsókn- argögnum hvers vegna ákveðið var að rannsaka pessa sjúklinga ekki frekar pó ábending hafi verið fyrir pví.

Pótt meirihluti sjúklinga hafi aðeins greinst einu sinni með gallrásarstein voru sjúklingar sem fengu endurtekna steina mun oftar með fylgikvilla í kjölfar aðgerðar eða meðferðar fyrsta gallrásarsteins. Pó hóparnir séu of litlir til að gera marktækniútreikninga og spurning hvort stærra úrtak hefði leitt pann mun skýrar í ljós, benda niðurstöðurnar til að aukin áhætta sé á að fá gallrásarstein eftir gallblöðrutöku hafi komið upp vandamál í aðgerð eða í kjölfar aðgerðar. Petta vekur upp pá spurningu hvort pörf sé á að fylgja peim sjúklingum betur eftir en venja er, til dæmis með mælingu á lifrarprófum eftir 6 vikur frá aðgerð.

Ákveðnir vankantar finnast á pessari rannsókn sem vert er að nefna. Bæði er vandamálið sem verið er að rannsaka ekki algengt og rannsóknarhópurinn lítill, sem gerir pað að verkum að erfitt er að fá fram marktækar niðurstöður hvað varðar mun á milli hópa. Rannsóknin var afturskyggn og einungis voru teknir með í rannsóknina sjúklingar sem leituðu aftur á Landspítala og voru greindir með gallrásarstein á fjögurra ára tímabili. Peir sjúklingar sem leituðu á aðra spítala hérlendis eða erlendis með sama vandamál og höfðu áður farið í gallblöðrutöku á Landspítala voru ekki teknir með í rannsóknina. Pó verður að teljast líklegt að flestir sem fengu einkenni gallrásarsteins hafi leitað á Landspítala til uppvinnslu en ekki annað, par sem spítalinn er með stærsta upptökusvæðið hérlendis. Einnig var mislangt frá pví að sjúklingar fóru í gallblöðrutöku og ekki voru liðin tvö ár frá aðgerð hjá öllum sjúklingum. Pví er mögulegt að fleiri hafi fengið gallrásarsteina síðar. Til að sneiða hjá pessu pyrfti framskyggna rannsókn par sem hópi sjúklinga eftir gallblöðrutöku á ákveðnu tímabili væri fylgt eftir. Á Landspítala eru framkvæmdar flestar gallblöðrutökur landsins auk pess sem hann hefur stærsta upptökusvæðið hvað varðar móttöku sjúklinga með bráð veikindi. Gera má ráð fyrir að langflestir sjúklingar sem fengu einkenni á pessum tíma hafi skilað sér inn í rannsóknina.

Okkar niðurstaða er að hægt sé að meðhöndla nær alla sjúklinga með gallrásarsteina eftir gallblöðutöku án skurðaðgerðar með röntgenrannsókn á gallvegum og brisgangi með holsjá. Pó meirihluti steina greinist innan tveggja ára verður ekki séð að grunur um gallrásarstein hafi átt að vakna við sjálfa gallblöðrutökuna nema í undantekningartilfellum.

\section{Pakkir}

Pakkir fá Ingibjörg Richter, Martin Ingi Sigurðsson og Pétur Sigurjónsson fyrir veitta aðstoð. 


\section{Heimildir}

1. Everhart JE, Khare M, Hill M, Maurer KR. Prevalence and ethnic differences in gallbladder disease in the United States. Gastroenterology 1999; 117: 632-9.

2. Stokes CS, Krawczyk M, Lammert F. Gallstones: environment, lifestyle and genes. Dig Dis 2011; 29: 191-201.

3. Völzke H, Baumeister SE, Alte D, Hoffmann W, Schwahn $\mathrm{C}$, Simon $\mathrm{P}$, et al. Independent risk factors for gallstone formation in a region with high cholelithiasis prevalence. Digestion 2005; 71: 97-105.

4. von Schönfels W, Buch S, Wölk M, Aselmann H, Egberts $\mathrm{JH}$, Schreiber S, et al. Recurrence of gallstones after cholecystectomy is associated with ABCG5/8 genotype. J Gastroenterol 2013; 48: 391-6.

5. Schofer JM. Biliary causes of postcholecystectomy syndrome. J Emerg Med 2010; 39: 406-10.

6. Jaunoo SS, Mohandas S, Almond LM. Postcholecystectomy syndrome (PCS). Int J Surg 2010; 8: 15-7.

7. Peterli R, Schuppisser JP, Herzog U, Ackermann C, Tondelli PE. Prevalence of postcholecystectomy symptoms: long-term outcome after open versus laparoscopic cholecystectomy. World J Surg 2000; 24: 1232-5.

8. Luman W, Adams WH, Nixon SN, McIntyre IM, HamerHodges D, Wilson G, et al. Incidence of persistent symptoms after laparoscopic cholecystectomy: a prospective study. Gut 1996; 39: 863-6.
9. Fenster LF, Lonborg R, Thirlby RC, Traverso LW. What symptoms does cholecystectomy cure? Insights from an outcomes measurement project and review of the literature. Am J Surg 1995; 169: 533-8.

10. Girometti R, Brondani G, Cereser L, Como G, Del Pin $\mathrm{M}$, Bazzocchi M, et al. Post-cholecystectomy syndrome: spectrum of biliary findings at magnetic resonance cholangiopancreatography. Brit J Radiol 2010; 83: 351-61.

11. Greenfield LJ (ed). Surgery: Scientific Principles and Practice. Lippincott-Raven, Fíladelfíu 1997.

12. Arnarson A, Hauksson $\mathrm{H}$, Marteinsson VT, Albertsson SM, Datye S. Gallblöðrunám með kviðsjártækni. Fyrstu 400 tilfellin á FSA. Læknablaðið 2003; 89: 35-40.

13. Viktorsdóttir O, Blöndal S, Magnússon J. Tíðni alvarlegra fylgikvilla gallkögunar. Læknablaðið 2004; 90: 487-90.

14. Videhult P, Sandblom G, Rudberg C, Rasmussen IC Are liver function tests, pancreatitis and cholecystitis predictors of common bile duct stones? Results of a prospective, population-based, cohort study of 1171 patients undergoing cholecystectomy. HPB (Oxford) 2011; 13: 51927.

15. Parra-Membrives P, Diaz-Gomez D, Vilegas-Portero R Molina-Linde M, Gomez-Bujedo L, Lacalle-Remigio JR. Appropriate management of common bile duct stones: a RAND Corporation/UCLA Appropriateness Method statistical analysis. Surg Endoscopy 2010; 24: 1187-94.
16. Möller M, Gustafsson U, Rasmussen F, Persson G, Thorell A. Natural Course vs Interventions to Clear Common Bile Duct Stones: Data From the Swedish Registry for Gallstone Surgery and Endoscopic Retrograde Cholangiopancreatography (GallRiks). JAMA Surg 2014; 149: 1008-13.

17. Ford JA, Soop M, Du J, Loveday BP, Rodgers M. Systematic review of intraoperative cholangiography in cholecystectomy. Brit J Surg 2012; 99: 160-7.

18. Sajid MS, Leaver C, Haider Z, Worthington T, Karanjia $\mathrm{N}$, Singh KK. Routine on-table cholangiography during cholecystectomy: a systematic review. Ann R Coll Surg Engl 2012; 94: 375-80.

19. Navaneethan U, Konjeti R, Venkatesh PG, Sanaka MR, Parsi MA. Early precut sphincterotomy and the risk of endoscopic retrograde cholangiopancreatography related complications: An updated meta-analysis. World J Gastrointest Endosc 2014; 6: 200-8

20. Liu Y, Su P, Lin S, Xiao K, Chen P, An S, Zhi F, Bai Y. Endoscopic papillary balloon dilatation versus endoscopic sphincterotomy in the treatment for choledocholithiasis: a meta-analysis. J Gastroenterol Hepatol 2012; 27: 464-71.

\section{ENGLISH SUMMARY}

\section{Choledocholithiasis after cholecystectomy at Landspítali - The National University Hospital of Iceland 2008-2011}

Thorey Steinarsdottir ${ }^{1}$, Elsa B. Valsdottir ${ }^{1,2}$, Pall Helgi Moller ${ }^{1,2}$

Introduction: Symptoms of choledocholithiasis can appear after cholecystectomy. Stones diagnosed during the first two years following surgery are assumed to have been present at the time of surgery. The purpose of this study was to study patients who presented with choledocholithiasis at Landspitali - The National University Hospital of Iceland, during the period 2008-2011, who had previously undergone cholecystecomy and to assess whether cholodocholithiasis is underdiagnosed at the time of cholecystectomy.

Material and methods: The study was retrospective, data was collected from medical records at Landspitali. Among recorded data were liver function tests, imaging results, time from surgery to diagnosis, treatment and complications.

Results: Forty patients presented with choledocholithiasis after previous cholecystectomy. Mean age was 50 years (20-89) and women were 24 (60\%). Mean time from surgery to diagnosis was 382 days. Diagnosis was confirmed with imaging in 35 (87.5\% cases). Thirty six $(90 \%)$ patients were treated with ERCP, one with PTC and one underwent open surgery. Three patients healed without treatment. Three patients developed complications from treatment. Thirty one $(77.5 \%)$ had choledocholithiasis in the first 2 years following surgery. Incidence of previous choledocholithiasis, elevated bilirubin or widening of the choledochus without visible stones where similar for those diagnosed with choledocholithiasis in the first two years and those diagnosed later. Conclusion: Majority of patients are treated without surgery. Most stones are diagnosed during the first two years following surgery. For the majority of cases it can not be concluded that stones should have been suspected at time of cholecystectomy. 